\title{
ダイコクネズえ下垂体摘出手術
}

\author{
本間運隆 \\ (名古屋大学震学部畜産学教室)
}

\section{Technic for hypophysectomy of rats}

\section{KazUTAKa Homma}

(Facultty of Agriculture, Nagoya University)

ダイコクネズミの下垂体摘出手術については著者等が 既に報告した1（1953）がその徏多くの人々からの御教 示受け，又著者自身手術を指等した間に気付いた点を 迫加してここに報告する。

1) 手術の諆備 器具としては一般の小動物用非術器

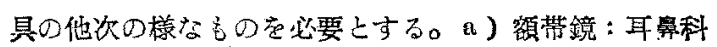
用の小型のもの老用いる。手術が永びくととが多いので 出来れば電源は小型トランスを用いる。b) 保定具：厚 板に金属整の頭部固定金具をとりつけ，主左右に薄手 のコルク板を接着したもの。ネズミの頭它金具に入れた 場合に頝部に少しわとりが出来る様に手街前に調整す、 る。c）開創器：細い鋏鉄線るコ型に曲げ一方索とがら してコルク板にさす。他端の創口に当る場所は平たくけ ずる。著者は 2 本しか用いないが5本位を用意して衏野

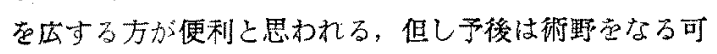

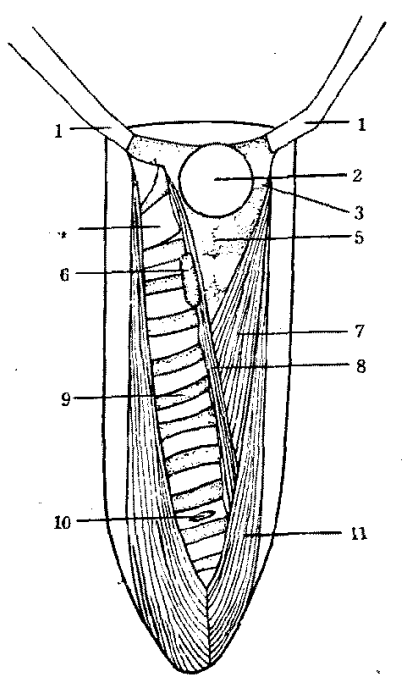

Explanation of figure

Showing the operative field

(1) Hooks (2) The position of point hole (3) Synchondrosis Sphenoccipitalis (4) Cartilago thyreoidea (5) Crista occipitalis (6) Thyroid grand (7) $M$. longus capitis and $M$. rectus capitis (8) $M$. sternothyreoideus (9) Trachea (10) The incised orifice for respiration (11) $M$. sternohyoideus 〈狭々手術学行つた方が良好である。d）菊科用ハンド ピース：Doriot 型がよい。㿠科用エンヂンの一式があ れば市分ないが，簡単なモーターにベルトでつないだも ので充分である。足蹬スキツギで操作する。e）下垂体

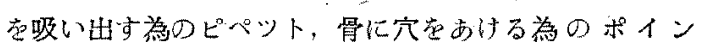
ト,デンタルピック等を必要である。以上の器具の寸法 等については前報〉を参照されたい。f)手術台の附近 にはビニール管定水流ポンプに取付けたもの等用意し， 手術中の出血及び気管内部の粘波の除去に用いる。g）

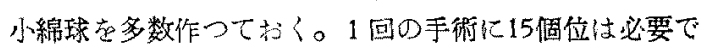
ある。

2）実施 ネッ゙ミ心柽くエーテル麻醉して背位に保定 し, 前肢は体侧に沿つて後方に引々，正中線上で頝部の

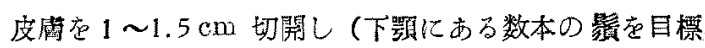
にしてそこから尾側に切開するもよい）。てれ以後銼は 一切用いない。先づ俥腺をピンセットで左右に分けると 気管を掩つている筋層が見える。甲状腺を傷つけね様注 意しててれを左右に正中線上で分け創口に開創用の鈎を かけて大きく開く。気管を左側の鉤に汃りると呼吸が出 来な?なるから小さいメスで乎早、気管に小さい切目を つけて, その附近の筋曆との間には小綿球を入れて呼吸 し易い様にしてやる。ここで気管中の站液を吸い出し， 甲状数骨の下方に見える小脂肪塊を目標としてピンセツ 卜の先に小棉球龺つけて筋を分けて行くと指先に横行す

る Synchondrosis Sphenoccipitalis な感ずる。それ

¿ Crista Occipitalis Externa との交点がポイントの 中心よりやや後にくる様に垂直にポイントをあてて骨に 穴をあけて硬脳膜を注意しつつ取出す。るしむまり力虑 入れすぎると下垂体堂傷つけるので吸い出すととが出来 なくなるから注意を要する。デンタルピックを用いると 便利である。穴にぴつたり合うピペット茧はめロで静か 飞吸うと多くの場合下垂体の前後葉が一体となつて吸い 出される。摘出が終つたら穴の中に一滴の油性ペニシリ ンを入れ直に創口を縫合して手術を終る。摘出後に出血 の亦る場合には小タンポンで穴をつめ暂く待ち完全に止 血をたしかめた後以後の操作に移る。次に手術中に起り 
易い失敗とその原因をまとめると以下の梯になる。a） 頭蓋底优しない前にかなりの出血のある場合 : 術野が 左か右にずれている場合である。気管を術者の左方に引 くので右側に偏する埸合が多い。偏つたまま深く入ると 預動脉を复つけ易く，を机をさける為汇は手術が大体正 中線上で行われていることに絶えず注意する必要があ る。動物の保定も正しくせねばなら奴。又甲状腺附近の

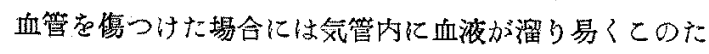
めに室息をするととがある。気管を报らのにあまり鋭い 器貝觉用いないととと, 気管の穴ななる可く小さくする とよい。 b) 骨に穴をあける場合に左右にずれること : 手が動感であるから練習により直すより途はない。 木片上に穴をありて練習奇す机ば容易に防げる。） 穴から下垂体が吸い出せない場合：硬媨膜の破片がうま くとり出せなかつた場合には䂸つた破片をとり出した後 には多くの場合吸出すととが出来る。尚破系の残つた場 合は何度吸つてす吸い出せないばかりではく大出血学伴 つたり，術後死亡するととが多い。穴汃小さ過きる場合 をある。 d)穴がうまくあいたのに世血の多い場合： ポイントが太すぎるのであるからやや細目のものを用い る。 e) 手術は哄常なく行われたにる拘らず間もなく 死亡する場合：手街が永びいて追加麻醉をした場合や麻 蠤にバルビタール剂を用いた場合を除けば，多くは術後 の脳底からの出血か，気管内に粘液の溜つた事による。 前者は骨片等を残さ奴様に注意することにより，又後者 は術後数回気管内粘液堂除去することによつて防ぐこと が出来る。 f) 栕れ間は正しい位置より尾側に穴を あけ易く，この場合には下垂体を見ることが出来好か すぐ判断がつく。

3）手術後の経過手術中に出血がなりれば1日後に は元気になり1䓢間後には創口も見分けがつかなるなる。 下垂体剔出動物に更に他の手術走行う場合，長時間を要 せ衫のでは, 剔出後 2〜3 日目に行うととが出来る。 体重は手術前に比して5\%程度の增減であれば気にかけ る必要はなく、下垂体摘出は必ずしも体重の減少のみを
来すものではない。特に日令が若いものでは多くのもの が体董がやや増加する。乎術の絬果の判定剖検以外に

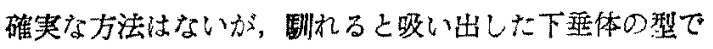
大体の判定が可能となる。冬期であれ优糹少くとす1 週間は保温に注意してやる。手術後 1 日目に摄食しない 乙衰弱し易いから，乘い食物を数回与えた後に通常の食 飳に移与様にする。

4) むすご 以上手術の概要と注意をのヘたが，著者 の手術の成功率はかなり良好になつたと思われる場合に 於て妇搭出が完全で永く生存したのは 80\% 程度であつ た。又1日に，手術可能な動物数は10 匹位であつて， 出来る丈動物は同腹のものを1日の間に手術してしまう

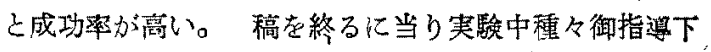

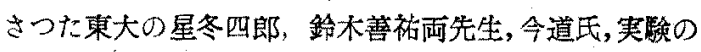
手助方してくれた浪速大学の志賀君に御礼申し上げる。 (1954.7. 26 受付)

文献

1) 本間，志䝷 (1953)：医学と生物学，28，（2）； $94 \sim 96$

\section{Résumé}

The method of hypophysectomy described here is the modified one originally described by Smith and developed by Selye, and may be applicable to mouse and guinea pig with little modification. The outline of the operation was reported previously with author and Shiga (1953).

This method has three abvantages: (a) No assistant is needed throughout operation, (b) the method of cutting bone is improved, so as not to bleed from the sinus in the bone, (c) the dura can be cut off with a dental point.

The operative field of paraphalyngeal hypophysectomy is shown in figure. 